Special issue of the International Conference on Computational and Experimental Science and Engineering (ICCESEN 2014)

\title{
Modeling and Simulation of a Photovoltaic Module in Different Operating Regimes
}

\author{
A.A. Jadallah*, D.Y. Mahmood and Z.A. Abdulqader \\ University Of Technology, Dep. of Electromechanical Engineering, Baghdad, Iraq
}

\begin{abstract}
Modern research focuses on the renewable energy sources such as solar energy. This paper presents the modeling and performance of a photovoltaic (PV) cell. A simulation code is built using MATLAB. Results show that the increase of solar radiation and of ideality factor of diode lead to an increase in the output power of PV module, while the increease of cell temperature and of the dark saturation current lead to a decrease of the power. Curves of $I-V$ and $P-V$ dependencies are presented for module having 50 branches connected in parallel, with each branch having 50 cells connected in series. Data for certain Iraqi governorates are taken and applied for proposed module.
\end{abstract}

DOI: 10.12693/APhysPolA.128.B-461

PACS: $72.40 .+\mathrm{w}, 77.80 .-\mathrm{e}$

\section{Introduction}

Recently, photovoltaic technology is recognized to be in the forefront of renewable electric power generation, because it can generate direct current without a heavy environmental impacts and contamination. The electrical output from a single cell is small, so multiple cells are connected and encapsulated (usually glass covered) to form a module (also called a panel). Many researchers have proposed in the literature several models of a photovoltaic module. Tsai et al. [1] have proposed a model, taking sunlight irradiance and cell temperature as input parameters. Salmi et al. [2] proposed a model of PV cell, based on the fundamental circuit for a solar PV cell, considering the effects of physical and environmental parameters. Tsai [3] has developed a novel model of PV module using Matlab/Simulink and verified it experimentally.

This paper focuses on the study of parameters that affect the PV cells and on how to model and simulate the cells connection and develop a module which has a specific number of branches connected in parallel, which form the whole PV module.

\section{PV cell modeling \\ 2.1. $P V$ cell general formulation}

The most common mathematical model employed to define the current-voltage characteristics of a PV cell (direct and reverse) was proposed by Bishop [4]. It is based on the equivalent circuit shown in Fig. 1. The analytical expression for the current in a PV cell, according to the model is:

$$
\begin{aligned}
& I=I_{\mathrm{Ph}}-I_{0}\left[\exp \left(\frac{e\left[V+I R_{\mathrm{s}}\right]}{N K T_{\mathrm{c}}}\right)-1\right] \\
& -\frac{\left(V+I R_{\mathrm{s}}\right)}{R_{\mathrm{sh}}} .
\end{aligned}
$$

\footnotetext{
*corresponding author; e-mail: dr_abd.allateef@yahoo.com
}

The shunt resistance is usually much higher than the load resistance, whereas the series resistance is much smaller than the load resistance. Thus less power is dissipated within the cell. Therefore these two resistances can be neglected.

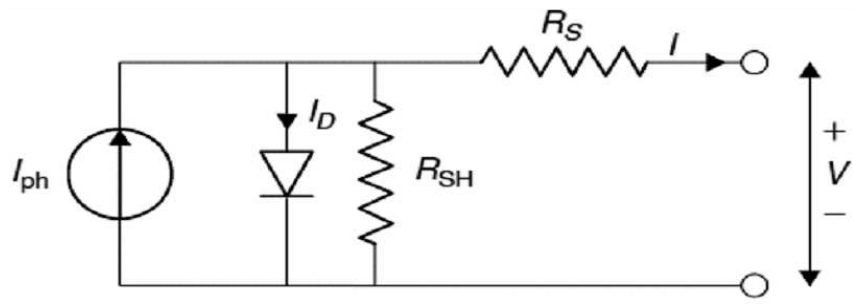

Fig. 1. Equivalent circuit of PV cell.

In the case of short circuit mode, the voltage will be equal to zero $(V=0)$ and the photon current is equal to short circuit current $\left(I_{\mathrm{Ph}}=I_{\mathrm{sc}}\right)$.

$$
I=I_{\mathrm{sc}}-I_{0}\left[\exp \left(\frac{e V}{N K T_{\mathrm{c}}}\right)-1\right]
$$

In case of open circuit, the current will be equal to zero, and the voltage will be $\left(V=V_{\mathrm{OC}}\right)$. Therefore, the formula which describes the open circuit voltage is as follows:

$$
V_{\mathrm{OC}}=N \frac{K T_{\mathrm{c}}}{e} \ln \left(\frac{I_{\mathrm{SC}}}{I_{0}}+1\right) .
$$

The power output can be expressed as:

$$
P=\left[I_{\mathrm{sc}}-I_{0}\left[\exp \left(\frac{e V}{N K T_{\mathrm{c}}}\right)-1\right]\right] V .
$$

According to PV cell characteristics, current will be maximum when the cell is short circuited $\left(I_{\mathrm{sc}}\right)$. In this case the voltage will be zero $(V=0)$. The voltage will be maximum when the cell's circuit is open $\left(V_{\mathrm{OC}}\right)$. In this case the current is zero $(I=0)$. Between the open and short circuit the power output is greater than zero. 
2.2. Influence of cell temperature, solar radiation, dark saturation current and diode ideality factor on $P V$ cell

The variation of cell temperature affects the reverse saturation current. It increases approximately as the third power of temperature [5]

$$
I_{0}=I_{0 \text { ref }}\left(\frac{T_{\mathrm{c}}}{T_{\text {ref }}}\right)^{3} \exp \left[\frac{E_{\mathrm{g}}}{N V_{\mathrm{t}}}\left(\frac{T_{\mathrm{c}}}{T_{\text {ref }}}-1\right)\right],
$$

where $E_{\mathrm{g}}$ is the band gap energy of the semiconductor.

The variation of solar radiation intensity also affects the short circuit current, according to the following formula $[6,7]$ :

$$
I_{\mathrm{SC}}=\left[I_{\mathrm{SC} \text { ref }}+K_{\mathrm{i}}\left(T_{\mathrm{c}}-T_{\mathrm{ref}}\right)\right] \frac{G}{G_{\mathrm{ref}}} .
$$

\section{PV cells connection}

In practice solar cells can be connected in series or in parallel. In the case of parallel and series connection the current can be estimated from the following Equation [8]:

$$
I=n_{\mathrm{p}} I_{\mathrm{sc}}-n_{\mathrm{p}} I_{0}\left[\exp \left(\frac{V}{N V_{\mathrm{t}} n_{\mathrm{s}}}\right)-1\right] .
$$

\section{Photovoltaic panels}

Cells are normally grouped into modules as shown in Fig. 2. PV cell modules consist of $N_{\mathrm{PM}}$ parallel branches and each branch has $N_{\mathrm{SM}}$ solar cells connected in series. The voltage at the module's terminals is denoted by $V^{\mathrm{M}}$, whereas the total generated current is denoted by $I^{\mathrm{M}}[9]$.

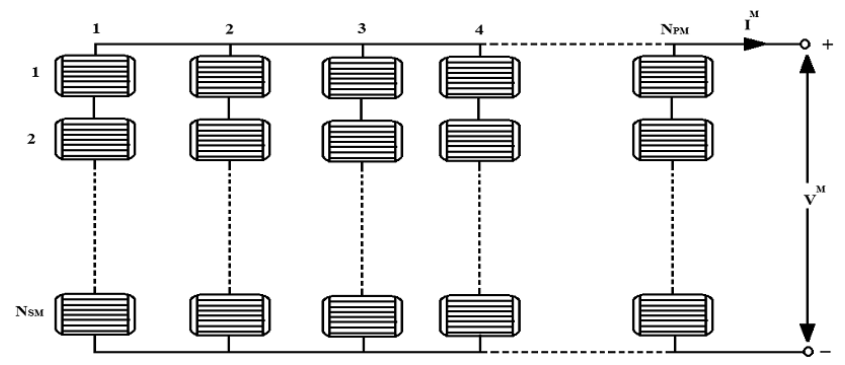

Fig. 2. Schematic diagram of a PV module consisting of $N_{\mathrm{PM}}$ parallel branches, each with $N_{\mathrm{SM}}$ cells in series.

A model of the PV module can be obtained by replacing each cell in Fig. 2 with an equivalent diagram from Fig. 1. The model, developed by Lorenzo [10] has the advantage that it can be used by applying only standard manufacturer supplied data for the modules and the cells. The current from a PV module $I^{\mathrm{M}}$ under arbitrary operation conditions is given by:

$$
I^{\mathrm{M}}=I_{\mathrm{sc}}^{\mathrm{M}}\left[1-\exp \left(\frac{V^{\mathrm{M}}+V_{\mathrm{OC}}^{\mathrm{M}}+R_{\mathrm{s}}^{\mathrm{M}} I^{\mathrm{M}}}{N_{\mathrm{SM}} V_{\mathrm{t}}^{\mathrm{C}}}\right)\right] .
$$

\section{Simulation of PV module performance}

It is necessary to take into account many parameters that affect the cell, such as cell temperature, solar radiation, diode ideality factor and dark saturation current. Simulation of PV module was carried out using a computer program written in Matlab. The flowchart of the program is shown in Fig. 3. In Iraq, the solar radiation is available in large enough quantities. This paper considers the solar radiation during one year in certain Iraqi governorates (Baghdad, Mosul and Basrah), as shown in Fig. 4

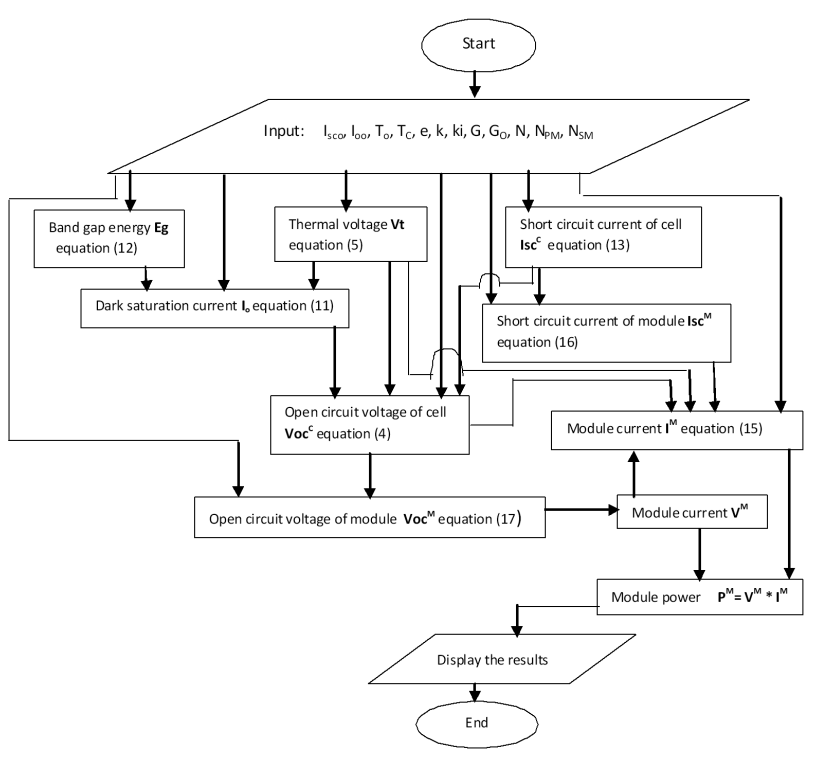

Fig. 3. Simulation flowchart.

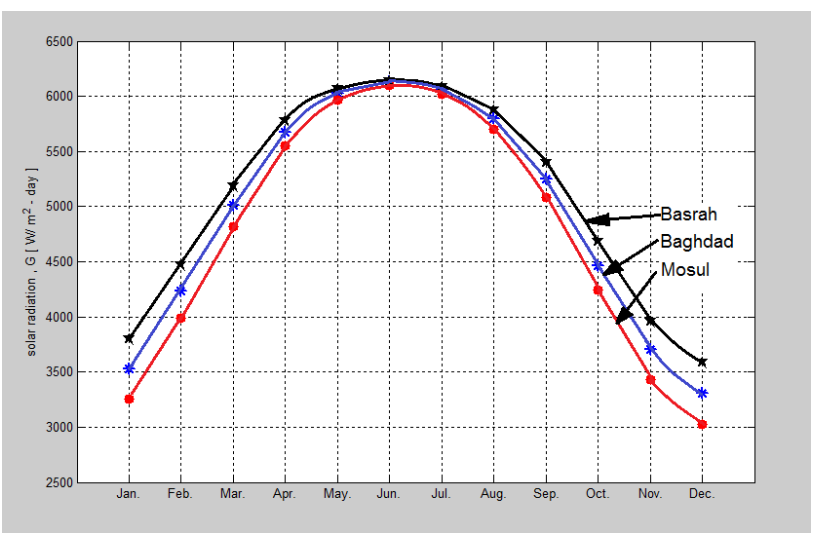

Fig. 4. Variation of solar radiation intensity in three Iraqi governorates, Baghdad, Mosul and Basrah, for one year period.

\section{Discussion and conclusions}

The effect of cell temperature on current and voltage is shown in Fig. 5. The voltage and cell output power tend 


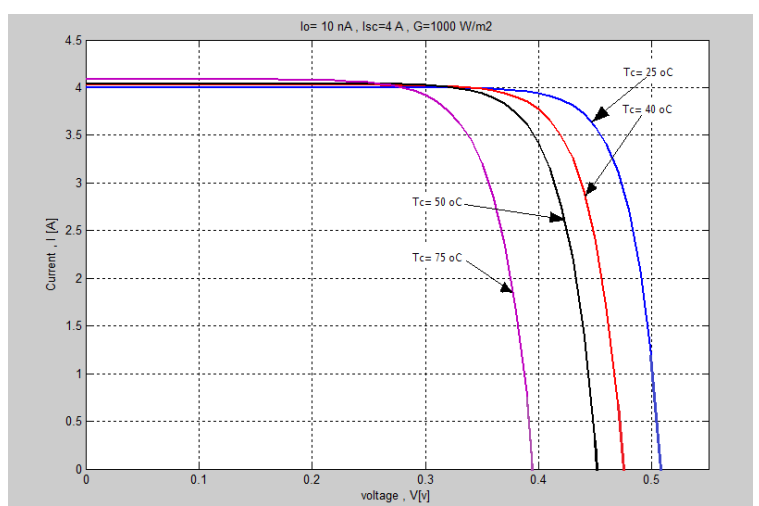

Fig. 5. Effect of $\mathrm{PV}$ cell temperature on $I-V$ characteristics.

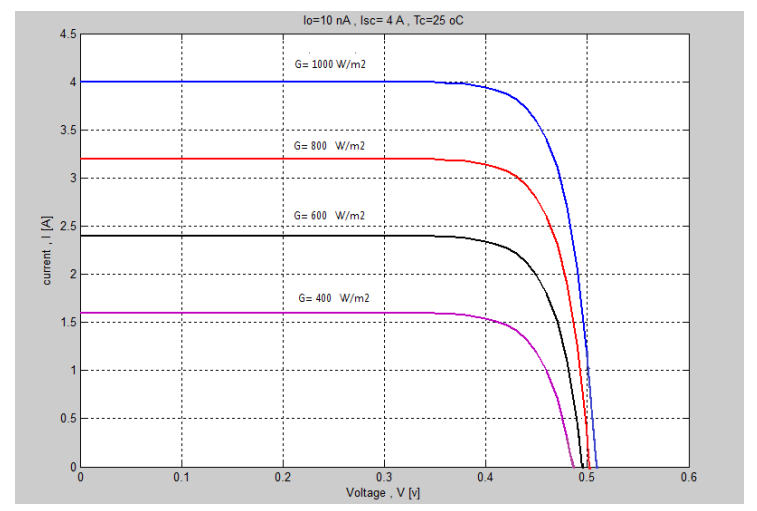

Fig. 6. $I-V$ curve of $\mathrm{PV}$ cell for various solar radiation intensities.

to decrease at higher temperatures, but there is no noticeable effect on the cell current. Thus, it is important to keep the cell temperature as low as possible, because higher temperatures have negative effect on output power of PV cell. Figure 6 presents the effect of solar radiation on PV cell, it reveals that higher solar radiation gives higher current and higher output power. Dark saturation current has an important influence on PV cell. Figure 7 shows that a higher dark saturation current produces a higher voltage and cell output power, however the current

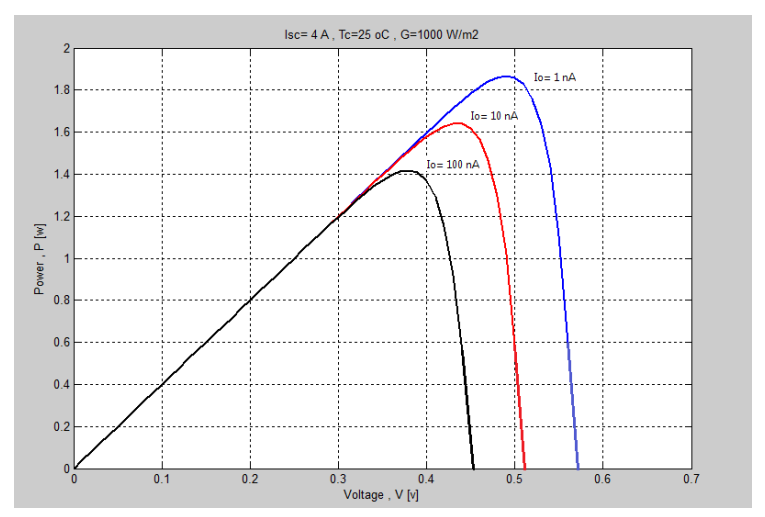

Fig. 7. $P-V$ curves for different values of dark saturation current.

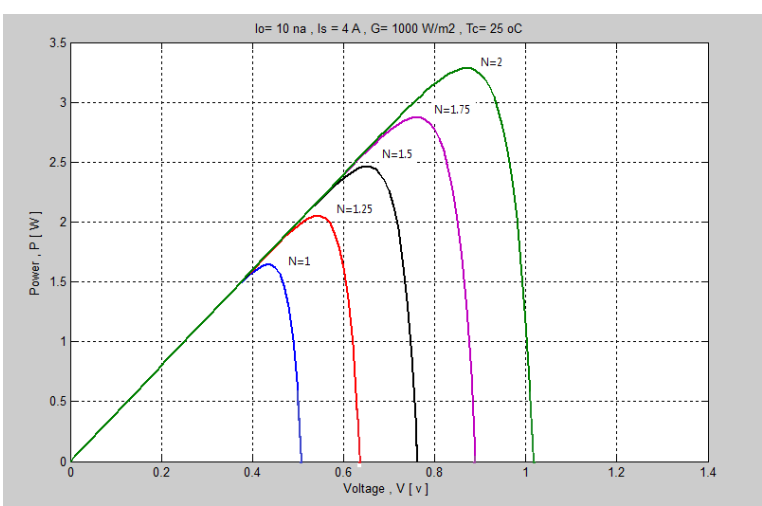

Fig. 8. $P-V$ curves for different values of ideality factor.

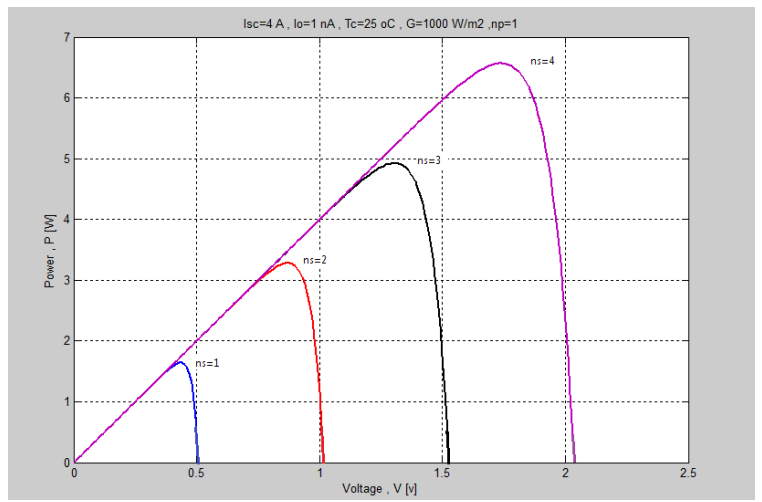

Fig. 9. $\quad P-V$ curves for PV cells connected in series.

remains constant, according to Eq. (1). It is clear that the voltage and cell output power have higher values at a higher ideality factor, however the current is not affected by the ideality factor, as shown in Fig. 8. Figures 9 and 10 shows results for $1,2,3$ and 4 cells, connected in series and in parallel, respectively. Figure 11 shows the $I-V$ and $P-V$ characteristics of a $\mathrm{PV}$ module constructed from 50 branches connected together in parallel, each branch having 50 cells connected in series. The $P-V$ curves for the month of December and annual variation of output power for such PV module, simulated for three

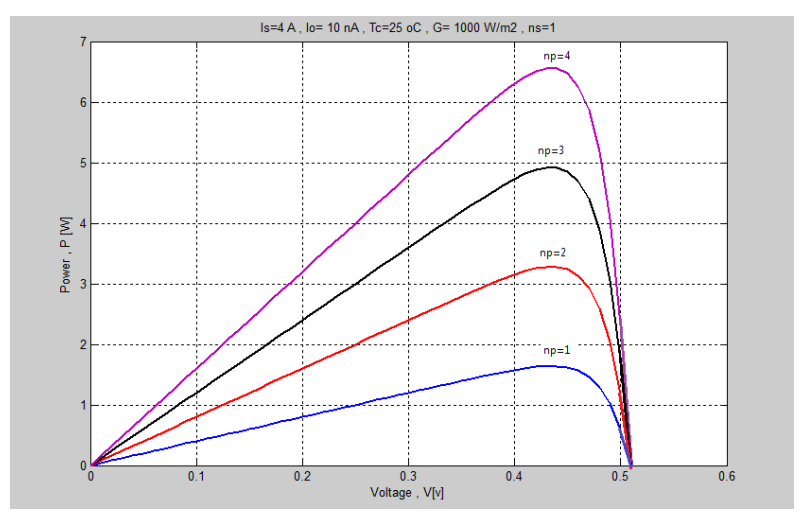

Fig. 10. $P-V$ curves for parallel connection of PV cells. 


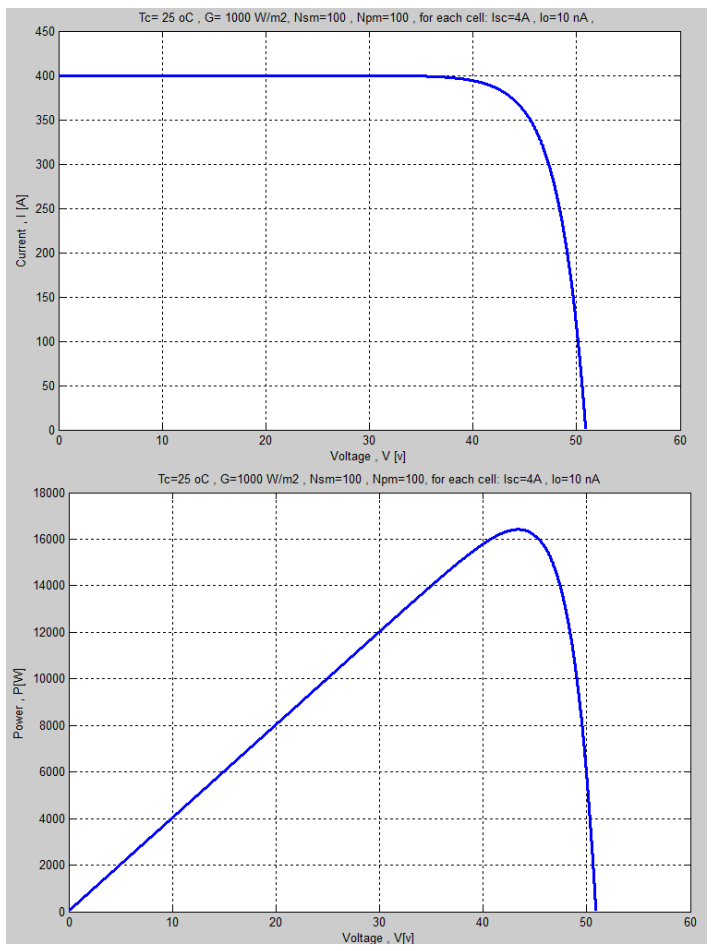

Fig. 11. (a) $I-V$ curve, (b) $P-V$ curve of $\mathrm{PV}$ module constructed from 50 branches connected together in parallel, each branch having 50 cells connected in series.

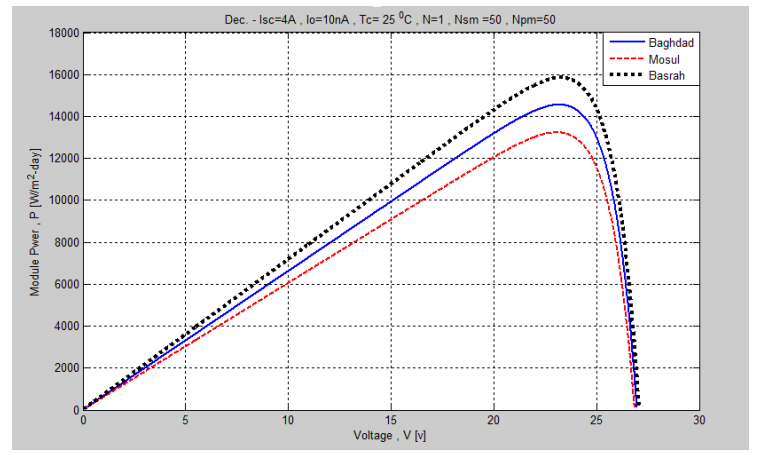

Fig. 12. $P-V$ characteristics for one month (December) of the proposed PV module having 50 branches with 50 cells in each branch.

Iraqi governorates are shown in Fig. 12 and Fig. 13, respectively. PV module situated in Basrah will produce more power than those placed in Baghdad or Mosul.

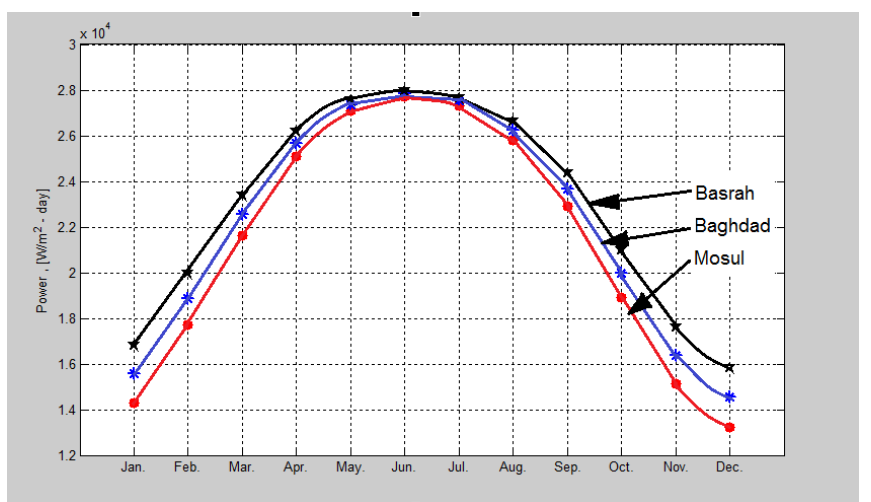

Fig. 13. Annual variation of output power of PV module, for three Iraqi governorates.

\section{References}

[1] H.L. Tsai, C.S. Tu, Y.J. Su, in: Proceedings of the World Congress on Engineering and Computer Science 2008, WCECS'08, San Francisco, USA.

[2] T. Salmi, M. Bouzguenda, A. Gastli, A. Masmoudi, Int. J. Renew. Energy Res. 2, 213-218 (2012).

[3] H.L. Tsai, Sol. Energy 84, 1318-1326 (2010).

[4] F. Iannone, G. Noviello, A. Sarno, Sol. Energy 62, 85 (1998).

[5] G.R. Walker, in Australasian Universities Power Engineering Conference, AUPEC '00, Brisbane, 2000.

[6] S. Nema, R.K. Nema, G. Agnihotri, IJEE 1, 487-500 (2010).

[7] Adel El Shahat, J. Theor. Appl. Inf. Technol. 16, 9 (2010).

[8] S. Nema, R.K. Nema, G. Agnihotri, Energ. Environ. 1-3, 487-500 (2010).

[9] S. Kalogiour, Solar Energy Engineering, Elsevier, Boston 2009.

[10] E. Lorenzo, Solar Electricity: Engineering of Photovoltaic System, Artes Graficas gala, S.L., Madrid 1994. 